\title{
E3 Ubiquitin Ligase TRIM Proteins, Cell Cycle and Mitosis
}

\author{
Santina Venuto ${ }^{1,2}$ and Giuseppe Merla ${ }^{1, *(1)}$ \\ 1 Division of Medical Genetics, Fondazione IRCCS Casa Sollievo della Sofferenza, Viale Padre Pio, \\ 71013 San Giovanni Rotondo, Foggia, Italy; venutosantina@gmail.com \\ 2 PhD Program, Experimental and Regenerative Medicine, University of Foggia, Via A. Gramsci, 89/91, \\ 71122 Foggia, Italy \\ * Correspondence: g.merla@operapadrepio.it
}

Received: 3 May 2019; Accepted: 23 May 2019; Published: 27 May 2019

check for updates

\begin{abstract}
The cell cycle is a series of events by which cellular components are accurately segregated into daughter cells, principally controlled by the oscillating activities of cyclin-dependent kinases (CDKs) and their co-activators. In eukaryotes, DNA replication is confined to a discrete synthesis phase while chromosome segregation occurs during mitosis. During mitosis, the chromosomes are pulled into each of the two daughter cells by the coordination of spindle microtubules, kinetochores, centromeres, and chromatin. These four functional units tie chromosomes to the microtubules, send signals to the cells when the attachment is completed and the division can proceed, and withstand the force generated by pulling the chromosomes to either daughter cell. Protein ubiquitination is a post-translational modification that plays a central role in cellular homeostasis. E3 ubiquitin ligases mediate the transfer of ubiquitin to substrate proteins determining their fate. One of the largest subfamilies of E3 ubiquitin ligases is the family of the tripartite motif (TRIM) proteins, whose dysregulation is associated with a variety of cellular processes and directly involved in human diseases and cancer. In this review we summarize the current knowledge and emerging concepts about TRIMs and their contribution to the correct regulation of cell cycle, describing how TRIMs control the cell cycle transition phases and their involvement in the different functional units of the mitotic process, along with implications in cancer progression.
\end{abstract}

Keywords: TRIMs; cell cycle; cancer; mitosis

\section{Introduction}

\section{Cell Cycle and Mitosis}

Precise replication of genetic material and its equal distribution into daughter cells are essential to maintain genome stability. The eukaryotic cell cycle refers to the series of events comprising the sequential actions, during proliferation, of DNA synthesis (S-phase), and cell division (M-phase) with intervening gap phases to allow cell growth (G1-phase) and to check the integrity of genomic material (G2-phase). The normal cell cycle is driven by the coordinated and sequential rise and fall of CDKs activity and their regulatory partners, the cyclins. Different phases of the cell cycle require different cyclins and the transition through the cell cycle phases is governed by the respective checkpoints that prevent the entry into the next phase until cellular or genetic defects are repaired [1,2] (Figure 1a). 
a

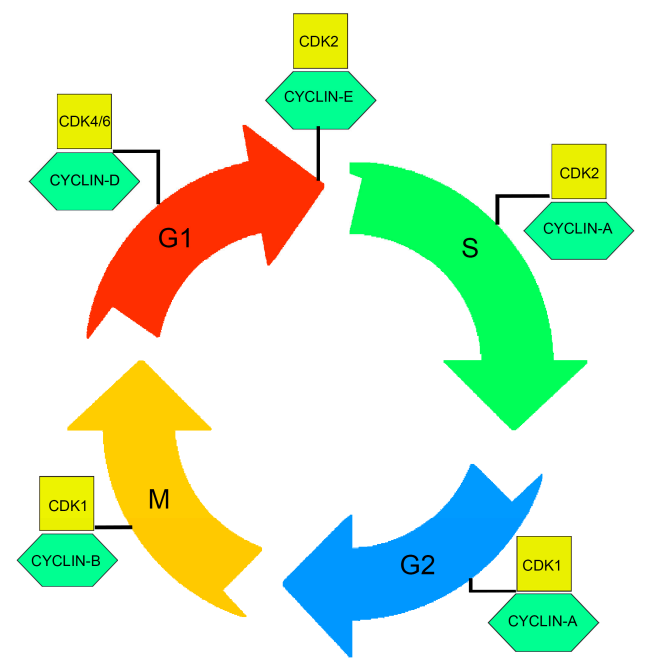

b

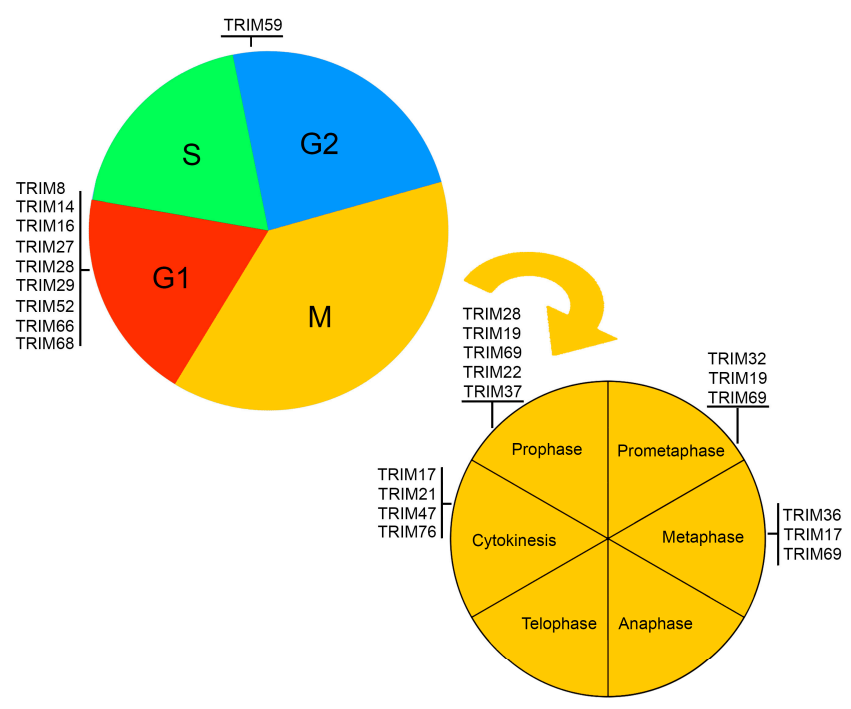

Figure 1. Tripartite motifs (TRIMs) regulate specific stages of cell cycle and mitosis. (a) Schematic representation of the cell cycle. Each of the main phases of the cell cycle-G1, S (when DNA synthesis occurs), G2 and mitosis-is controlled by CDKs, together with their regulatory partner proteins, the cyclins. Different phases of the cell cycle require different cyclins and the coordination between CDKs levels and the respective checkpoints prevent the entry into the following phase until cellular or genetic defects are repaired. (b) The critical and major TRIMs responsible of cell cycle phase transitions (up) and mitotic progression (down) are schematically represented within the phases they specifically are involved in.

Among the different phases of the cell cycle, mitosis is a delicate event that must be executed with high fidelity to ensure genomic stability, since genetic material has to be duplicated and each chromosome must be segregated into two daughter cells. Each of the daughter cells must receive an exact copy of the genetic material, and defects in chromosome segregation has been linked to tumorigenesis [3].

The onset of mitosis is typically marked by nuclear envelope breakdown, condensation of the replicated DNA in chromosomes, and subsequently centrosomes separation, during prophase. Then, an increase in the frequency of microtubule shrinkage events allows the interaction between dynamic microtubule plus-ends and the condensed chromosomes. 
During prometaphase, the individualized chromosomes attach their kinetochores to the microtubules and congress to the center of the microtubule array. In addition to the kinetochore fibers, both the interpolar and the astral microtubules contribute to the spindle bipolar structure. When all of the chromosomes are bi-oriented and aligned, the cell is in metaphase, with sister kinetochores attached to microtubules from opposite spindle poles (bipolar attachment). The correct attachment is then stabilized, raising the alignment of sister chromatids at the metaphase plate, and followed by their segregation toward the opposite spindle poles in anaphase [4]. After successful chromosome segregation, the spindle microtubules undergo a dramatic reorganization, forming the spindle midzone. Telophase marks the reformation of the nuclear envelopes around daughter cells nuclei, as the cytokinetic furrow pinches the cell into two. Cytokinesis begins with the formation of the midbody, composed of the remnants of the spindle midzone and in the final step the plasma membranes resolve in a process called abscission [5]. In mammalian cells abscission fails if chromosomes are pulled apart erroneously or if the anaphase spindle midzone is not properly formed, leading to regression of the cleavage furrow and the formation of multinucleated cells [6-8].

\section{TRIMs and Cell Cycle Progression}

The tripartite motif (TRIM) family proteins, also known as RING, B-box, and coiled-coil (RBCC) family, are characterized by an N-terminal TRIM region containing three zinc-binding domains, a RING (R) domain and one or two B boxes (B1 box and B2 box), and a coiled-coil region [9]. There are more than 80 known TRIM protein genes in humans [10] that are involved in various cellular processes such as apoptosis, cell cycle regulation, viral response, cell proliferation, oncogenesis, and antiviral defense. Consistently, their alteration results in many distinct pathological conditions and a wide variety of diseases including cardiovascular, neurological, immunological diseases, musculoskeletal diseases, developmental disorders, as well as various forms of cancer [10-16].

The RING domain gives to the TRIM proteins a role as E3 ubiquitin ligases in the ubiquitination process $[9,12]$. In this system, TRIM proteins bind to the substrates determining their fate. The most common consequence is the ubiquitin-mediated protein degradation through the $26 \mathrm{~S}$ proteasome, where the target proteins are ubiquitin-tagged and thus destroyed [17]. Together with proteasomal degradation, conjugation of ubiquitin to specific substrate proteins also modulates and ensures fidelity to many cellular processes, including intracellular signaling, innate immunity, transcription, autophagy, and carcinogenesis $[10,12]$. These different fates of the substrate proteins depend on the lysine of the ubiquitin moiety used for isopeptide bond formation [18-22]. For instance, K48-polyubiquitin chains manage proteasomal degradation, while K63-polyubiquitin conjugates are involved in non-proteasomal pathways, as intracellular signaling, DNA repair, and the endosomal-lysosomal system [23]. Of relevance, the control of the cell cycle, and in particular of mitosis, is one of the cellular processes that have to be faithfully coordinated and regulated by ubiquitination [5].

\subsection{TRIMs Regulate Phase Transitions during the Cell Cycle}

A number of TRIM proteins are involved in the control of cell growth and cell cycle transition phases (Figure 1b). A common effect of most TRIM proteins, when silenced or knocked-down, is the increase of the percentage of cells in G0/G1 and the reduction of the fraction of cells in S or G2-M phases. Specifically, TRIM8, TRIM14, TRIM27, TRIM28, TRIM29, TRIM52, TRIM59, TRIM66, and TRIM68 led to cell cycle arrest when depleted or silenced [24-35].

For an optimal cell cycle progression and cell proliferation, TRIM proteins act on crucial factors like p53 and/or on important pathways, including JAK/STAT signaling. The Janus kinase (JAK)/signal transducer and activator of transcription (STAT) pathway is a highly conserved cellular cascade which connects the extracellular signaling from growth factors and cytokines with the nuclear transcriptional machinery [36]. Cytokine-induced activation of the JAK/STAT3 pathway leads to JAK2 recruitment and STAT3 phosphorylation and dimerization. Then, the translocation of the STAT3 dimer from the cytoplasm to the nucleus alters the transcription of many genes that play a central role in proliferation, 
migration, survival, and resistance to apoptosis [37]. Deregulation of the JAK/STAT pathway leads to the activation of several genes involved in cell cycle progression, including cyclinB [38], p16, p21, p27, and others that control CDKs expression [39].

TRIM52 ablation, for instance, increases the level of activated p53 (pSer15) and one of its major targets, the cyclin-dependent kinase inhibitor p21. Induction of p21 by activated p53 inhibits cyclinE/CDK2 thereby preventing G1/S transition [40]. Additionally, TRIM28 knockdown significantly raises the expression of p21 and slightly alters p53 [24,26]. In human osteosarcoma cell lines, TRIM8 physically interacts, stabilizes, and activates p53 protein, resulting in a suppression of cell proliferation due to a p53-dependent cell cycle arrest in G1 [33]. Furthermore, both TRIM8 and TRIM29 may exert effect on cell cycle progression through their association with the JAK/STAT signaling pathway. TRIM29 knockdown increases the level of JAK2 and STAT3 phosphorylation, while TRIM8 interacts with and promotes STAT3 transcriptional activity with a consequent deregulation of STAT3 target genes that are directly involved in cell cycle progression [25,32]. Yet it was demonstrated that an enforced expression of TRIM14 leads to a decreased percentage of cells in the G1 phase along with an increase in S-phase cells [41].

\subsection{TRIMs, Cell Cycle Transitions, and Cancer Progression}

\subsubsection{TRIMs Involved in Cell Cycle Control Regulate Cancer Progression}

Many TRIMs regulating the cell cycle are involved in different types of cancer (Table 1). TRIM8 is downregulated in a number of tumors, including clear cells renal cell carcinoma (ccRCC), anaplastic thyroid carcinoma (ATC), and glioma (GM) [34,42]. In glioma tissues and cell lines, TRIM8 expression inversely correlates with tumor grade. Moreover, restored TRIM8 expression in patients glioma cell lines suppresses the tumor growth and induces a significant reduction of the clonogenic potential [43]. TRIM28 expression is positively correlated with cancer prognosis in specific cancer types as widely described in [44]. Higher TRIM28 gene expression has been linked to breast cancer, hepatocellular carcinoma (HCC), and prostate tumors [44-46].

Also, over-expression of TRIM28 is associated with poor outcome in GM patients [24], while TRIM52 controls cell cycle with a reduced proliferation speed and a compromised cycle progression in U87MG and A172 glioblastoma (GBM) cell lines [26]. Additionally, TRIM52 up-regulation promotes HCC cell proliferation, migration and invasion, is highly expressed in lung and colorectal cancer (CRC) cells and plays and oncogenic role in ovarian cancer (OC) $[27,35,47,48]$. TRIM68, TRIM27, and TRIM29 participate in the regulation of CRC tumorigenesis. TRIM29 negatively regulates migration and invasion of squamous cell carcinomas (SCC) and exerts an opposite oncogenic role in CRC, non-small cell lung carcinoma (NSCLC), lung squamous cancer and gastric cancer (GC) [25,49-52].

TRIM68 inhibits, while TRIM27 promotes CRC cells proliferation [53,54]. Additionally, TRIM27 is also involved in other types of cancer like intraductal carcinomas (IDCs) of salivary glands and ovarian cancers [55-57]. TRIM14 plays an oncogenic role and may be a prognostic factor and potential therapeutic target in osteosarcoma (OS). Upregulation of TRIM14 induces the growth, migration, and invasion of OS cells in vitro, promoting tumorigenesis [41]. TRIM14 is also up-regulated in human GBM and correlates with GBM progression with a specific role in tumor invasion and epithelial-mesenchymal transition (EMT) [58]. It is also correlated to CRC and GCs, promoting cell migration and invasion [59,60]. Yet, TRIM66 is overexpressed in NSCLC and controls invasion, migration, and proliferative capacities of lung cancer (LC) cells [61,62]. Then, in OS carcinogenesis, TRIM66 suppresses apoptosis pathway and promotes TGF- $\beta$ signaling [30].

TRIM16 is central for the differentiation of neuroblastoma (NB) cells. Its overexpression decreases proliferation in NB, lung, breast, and skin cancer cell lines through a down regulation of cell cycle factors E2F1 and pRB [63]. Moreover TRIM16 has a tumor suppressor role, inhibiting the migration, invasion, and the EMT in OC cells and in HCC [64,65]. Finally, among TRIMs involved in cell cycle progression, TRIM59 plays and oncogenic role in a multiplicity of different cancers. TRIM59 protein 
levels are significantly high in non-small cell lung carcinoma (NSCLC) [29] and its expression is significantly elevated in cervical cancers, epithelial ovarian cancer (EOC), cholangiocarcinoma (CCA) tissues and cells, breast cancer, and CRC [28,66-68]. TRIM59 also serves as a pro-oncogenic protein in promoting the progression of renal cell carcinoma (RCC) [69].

\subsubsection{TRIMs Control Cancer Progression Regardless of Cell Cycle Regulation}

Other TRIMs, although do not exert a specific role in the regulation of cell cycle phase transitions, are yet involved in controlling carcinogenesis and cancer progression (Table 1). Most of these TRIMs, like TRIM11 [70-74], TRIM23 [75], TRIM24 [76], TRIM25 [77-79], TRIM31 [80], TRIM37 [81], TRIM47 [82,83], TRIM65 [84], and TRIM71 [85] are up-regulated in cancer cells and tissues, playing an oncogenic role in different types of cancer. These TRIMs are often associated with unfavorable prognosis and promote cancer cells proliferation and migration, being often associated with proteins of central signaling pathways. On the other side, TRIMs like TRIM2 [86], TRIM3 [87,88], TRIM15 [89,90], TRIM26 [91], TRIM36 [92] TRIM45 [93], TRIM50 [94], TRIM58 [95,96], and TRIM62 [97] exert a tumor suppressor role, inhibiting cell proliferation and migration as well as promoting apoptosis. Finally, other TRIMs like TRIM32 [98-100] and TRIM44 play both an oncogenic and tumor suppressor role in different tumors [101-107].

The role of many TRIMs in cancer is closely related to their E3 ubiquitin ligase activity $[78,80,82,93]$. Among them, TRIM25 has an oncogenic role in colorectal cancer (CRC), gastric cancer (GC) and prostate cancer (PC) [77-79]. In PC TRIM25 is the E3 ubiquitin ligase of Ets related gene (ERG), an important transcription factor central for prostate cancers progression. TRIM25 as an ubiquitin ligase, targets ERG, mediating ERG polyubiquitination and stabilization in prostate cancer [78]. Then, TRIM31 is upregulated in HCC cells and exerts its oncogenic effect promoting the E3 ligase-mediated K48-linked ubiquitination and degradation of tuberous sclerosis complex (TSC) 1 and TSC2, the upstream suppressor of mTORC1 pathway. TRIM31 further overactivates mTORC1 oncogenic pathway [80]. Also TRIM45 exerts its tumor suppressor role using its E3 ligase activity to stabilize and activate p53 in glioma. In particular, TRIM45 conjugates K63-linked polyubiquitin chain to p53, thereby inhibiting the availability of p53 to the K48-linked polyubiquitination and consequent degradation [93]. Finally, TRIM47 plays an oncogenic role in CRC and PC [82,83]. It was recently reported that, as an E3 ubiquitin ligase, TRIM47 increases SMAD4 ubiquitination and consequent degradation. SMAD4 normally causes growth and invasion in human CRC cells, thus TRIM47 action inhibits CRC proliferation and metastasis [82].

Table 1. TRIMs' roles in cancer. TRIM family members that control cell cycle progression have different role in controlling cancer development and progression.

\begin{tabular}{cccc}
\hline TRIM & Type of Cancer & Role & Reference \\
\hline TRIM2 & ccRCC & tumor suppressor & {$[86]$} \\
\hline TRIM3 & CC & tumor suppressor & {$[87]$} \\
& HCC & tumor suppressor & {$[88]$} \\
\hline TRIM8 & GM & tumor suppressor & {$[43]$} \\
& RCC & tumor suppressor & {$[42]$} \\
& ATC & tumor suppressor & {$[34]$} \\
\hline TRIM11 & PC & oncogene & {$[70]$} \\
& OC & oncogene & {$[71]$} \\
& LC & oncogene & {$[72]$} \\
& HCC & oncogene & {$[73,74]$} \\
\hline TRIM14 & OS & oncogene & {$[41]$} \\
& GC & oncogene & {$[60]$} \\
& CRC & oncogene & {$[59]$} \\
& GBM & oncogene & {$[58]$} \\
\hline
\end{tabular}


Table 1. Cont.

\begin{tabular}{|c|c|c|c|}
\hline TRIM & Type of Cancer & Role & Reference \\
\hline \multirow[t]{2}{*}{ TRIM15 } & GADC & tumor suppressor & [89] \\
\hline & CRC & tumor suppressor & [90] \\
\hline \multirow[t]{3}{*}{ TRIM16 } & $\mathrm{NB}, \mathrm{LC}, \mathrm{SC}, \mathrm{BC}$ & tumor suppressor & {$[63]$} \\
\hline & $\mathrm{HCC}$ & tumor suppressor & [65] \\
\hline & OC & tumor suppressor & {$[64]$} \\
\hline TRIM23 & GC & oncogene & [75] \\
\hline TRIM24 & CRC & oncogene & [76] \\
\hline \multirow[t]{3}{*}{ TRIM25 } & CRC & oncogene & [77] \\
\hline & PC & oncogene & [78] \\
\hline & GC & oncogene & [79] \\
\hline TRIM26 & $\mathrm{HCC}$ & tumor suppressor & [91] \\
\hline \multirow[t]{3}{*}{ TRIM27 } & CRC & oncogene & [54] \\
\hline & IDC & oncogene & [55] \\
\hline & OC & oncogene & {$[56,57]$} \\
\hline \multirow[t]{4}{*}{ TRIM28 } & GM & oncogene & [24] \\
\hline & PC & oncogene & [44] \\
\hline & $\mathrm{HCC}$ & oncogene & [46] \\
\hline & $\mathrm{BC}$ & oncogene & [45] \\
\hline \multirow[t]{5}{*}{ TRIM29 } & CRC & oncogene & [25] \\
\hline & NSCLC & oncogene & [50] \\
\hline & LC & oncogene & [51] \\
\hline & GC & oncogene & [52] \\
\hline & SCC & tumor suppressor & [49] \\
\hline TRIM31 & $\mathrm{HCC}$ & oncogene & [80] \\
\hline \multirow[t]{3}{*}{ TRIM32 } & $\mathrm{LC}$ & oncogene & [99] \\
\hline & GC & oncogene & [108] \\
\hline & NB & tumor suppressor & [100] \\
\hline TRIM36 & PC & tumor suppressor & [92] \\
\hline TRIM37 & GM & oncogene & [81] \\
\hline \multirow[t]{7}{*}{ TRIM44 } & CRC & tumor suppressor & [101] \\
\hline & PTC & oncogene & [103] \\
\hline & PC & oncogene & [105] \\
\hline & $\mathrm{BC}$ & oncogene & [104] \\
\hline & NSCLC & oncogene & [106] \\
\hline & TGCT & oncogene & [107] \\
\hline & HEC & oncogene & [102] \\
\hline TRIM45 & GM & tumor suppressor & [93] \\
\hline \multirow[t]{2}{*}{ TRIM47 } & CRC & oncogene & [82] \\
\hline & PC & oncogene & [83] \\
\hline TRIM50 & $\mathrm{HCC}$ & tumor suppressor & [94] \\
\hline \multirow[t]{3}{*}{ TRIM52 } & GM & tumor suppressor & [26] \\
\hline & OC & oncogene & [48] \\
\hline & $\mathrm{HCC}$ & oncogene & [27] \\
\hline \multirow[t]{2}{*}{ TRIM58 } & LADC & tumor suppressor & [96] \\
\hline & CRC & tumor suppressor & [95] \\
\hline \multirow[t]{4}{*}{ TRIM59 } & NSCLC & oncogene & [29] \\
\hline & CCA & oncogene & [66] \\
\hline & $\mathrm{BC}$ & oncogene & [67] \\
\hline & EOC & oncogene & {$[109,110]$} \\
\hline
\end{tabular}


Table 1. Cont.

\begin{tabular}{cccc}
\hline TRIM & Type of Cancer & Role & Reference \\
\hline & RCC & oncogene & {$[69]$} \\
& Bca & oncogene & {$[111]$} \\
& CRC & oncogene & {$[68]$} \\
& OS & oncogene & {$[112]$} \\
& PC & oncogene & {$[113]$} \\
& CC & oncogene & {$[28]$} \\
\hline TRIM62 & AML & tumor suppressor & {$[97]$} \\
\hline TRIM65 & UCB & oncogene & {$[84]$} \\
\hline TRIM66 & OS & oncogene & {$[30]$} \\
& NSCLC & oncogene & {$[61,62]$} \\
\hline TRIM68 & CRC & tumor suppressor & {$[31]$} \\
\hline TRIM71 & NSCLC & oncogene & {$[85]$} \\
\hline
\end{tabular}

ccRCC: clear cells renal carcinoma; CC: cervical cancer; HCC: hepatocellular carcinoma; GM: glioma; RCC: renal cell carcinoma; ATC: anaplastic thyroid carcinoma; PC: prostate cancer; OC: ovarian cancer; LC: lung cancer; OS: osteosarcoma; GC: gastric cancer; CRC: colorectal cancer; GBM: glioblastoma; GADC: gastric adenocarcinoma; NB: neuroblastoma; SC: skin cancer; BC: breast cancer; NSCLC: non-small cell lung carcinoma; IDC: intraductal carcinoma; SCC: squamous cell carcinoma; PTC: papillary thyroid cancer; TGCT: testicular germ cell tumor; HEC: human esophageal cancer; LADC: lung adenocarcinoma; CCA: cholangiocarcinoma; EOC: epithelyal ovarian cancer; Bca: bladder cancer; AML: acute myelod leukemia; UCB: bladder urothelial carcinoma).

\section{TRIMs and the Mitotic Spindle Machinery}

\subsection{TRIMs and Their Relationship with the Centrosomes and Spindle Poles}

In multicellular eukaryotes, the mitotic spindle is made up of microtubules extending from two opposing spindle poles. To ensure the accurate distribution of the DNA during mitosis, a specialized macromolecular complex termed the kinetochore assembles onto the centromere of each chromosome [114]. The kinetochore-microtubule interface is critically important, as depolymerization of kinetochore-associated microtubules ultimately provides the driving force for chromosome segregation [115]. The primary microtubules organizing centers in human cells are named centrosomes and are important for the regulation of normal cell cycle progression and cell division. During mitosis, centrosome duplication and subsequent separation guarantee the formation of the mitotic spindle and the proper chromosomal segregation, in order to form stabilized daughter cells with the correct amount of DNA in each cell [116]. The centrosome is duplicated once during a normal cell cycle, starting at the G1 phase and completed by the end of the G2 phase [117]. Deregulation of this duplication machinery increases the number of centrosomes, raising the formation of multipolar spindles and thereby leading to aneuploidy and chromosomal instability. Centrosomal amplification has been associated with the initiation and progression of multiple malignancies and is related to a more aggressive tumor biology [116]. Together with centrosomes, other organelles that ensure reliable segregation of chromosomes during mitosis are the spindle poles [118].

Notably, a subgroup of TRIM/RBCC proteins has been shown to share a common domain (COS/FN3/B30.2) at the C-terminal of the proteins, necessary for the microtubule binding [119]. TRIMs proteins RING-finger, B-Box, and coiled-coil (RBCC) domain can be found in isolation or in combination with C-terminal domains, including COS, FN3 and B30.2 domains. The COS domain is a two $\alpha$-helical coils motif, responsible for dimerization and microtubule association [119]. The FN3 domain is a fibronectin type III motif that can contain DNA binding sites [120]. Finally, the B30.2 domain consists of a SPRY domain preceded by a region containing a "PRY" motif and is involved in protein-protein interactions [121]. 
TRIM proteins can control cell division during the transitions between the different phases of the cell cycle and a number of TRIM proteins co-localize with or are important for the regulation of key components of the mitotic spindle, including kinetochore, centrosomes and midbodies (Figure 1b).

Remarkably, some TRIM proteins localize at centrosomes and spindle poles and are important in the coordination of centrosome duplication and in the maintenance of the genome stability, ensuring a reliable chromosomes segregation [100,122-126]. Among them, TRIM28 and PML3/TRIM19 are associated with centrosomes and/or spindle poles and maintain genome integrity by preventing centrosome amplification through the control of the appropriate number of centrosome in mammalian cells [122,125]. Other TRIM proteins like TRIM69A and TRIM22 co-localize with centrosomes throughout the cell cycle and are essential for centrosome clustering [123,124], while TRIM32 localizes at spindle poles during mitosis [100]. Among TRIMs that have targets directly involved in the regulation of centrosomes clustering and spindle poles functions, TRIM28, TRIM19, and TRIM32 regulate NPM1, Aurora A, and MYCN, respectively. TRIM28 acts as an E3 SUMO ligase enhancing the SUMOylation and increasing the centrosome localization of NPM1, a nucleus and cytoplasm shuttle protein that coordinates centrosome duplication and whose SUMOylation contributes to centrosomal localization [125,127]. PML3/TRIM19 physically interacts with and represses Aurora A, a serine/threonine protein kinase whose overexpression induces centrosome amplification [128]. TRIM19 also colocalizes with $\alpha$-tubulin at the spindle poles and its depletion leads to aberrant mitosis and genome instability [122].

TRIM32 localizes at the spindle poles during mitosis through a recruitment mediated by Cdk1/cyclin B phosphorylation [100]. In particular, TRIM32 and MYCN both localize at spindle poles where they physically interact, and TRIM32 rapidly poly-ubiquitinylates MYCN protein destining it to degradation via the proteasome system. Acting against MYCN, TRIM32 is a positive regulator of an important physiological process named asymmetric cell division (ACD), whose regulation is mediated by the spindle pole-associated ubiquitin-proteasome system [100,129]. Since misregulation of the ACD may lead to tumorigenesis [130], TRIM32 is also important for the induction of complete ACD, particularly in human neuroblastoma [100].

Other TRIMs control the centrosomes number with an activity directly related to their RING domain [124]. TRIM69A is associated with spindle poles and promotes centrosomal clustering, being essential for the formation and regulation of the mitotic spindle. TRIM69A plays a critical role in supporting mitotic fidelity, as TRIM69-depleted cells show a number of mitotic defects, including micronucleation and multipolar spindle formation, particularly in NSCLC [124]. As an E3-ligase, TRIM69A localization at centrosomes is dependent upon its E3-ligase activity through an intact RING domain [124]. Finally, TRIM37 plays an intriguing role in the regulation of centrosomal components, deregulating p53 stabilization and allowing cells to escape arrest following centrosome loss [126].

Overall these experimental data indicate that the co-localization of TRIMs with centrosome and spindle poles, together with their E3-ligase activity, regulate central component of the mitotic spindle machinery, via different mechanisms.

\subsection{TRIMs Are Involved at the Kinetochore Level}

The centromere is the site for the recruitment of the kinetochore, a large protein complex central for the alignment and segregation of chromosomes from the onset of mitosis, ensuring exclusive connection of sister chromatids to the opposite spindle poles. The kinetochore contains a large number of protein components that prevent erroneous attachment of microtubules, ensuring timely segregation during mitosis [131].

Among TRIM proteins, TRIM69, TRIM36, and TRIM17 play a role in chromosome segregation and cell-cycle regulation interacting with and regulating proteolysis and proteasome-dependent degradation of several kinetochore proteins [17,124,132].

TRIM69 is essential for the proper attachment of microtubules to kinetochores as its depletion increases BUBR1 occupancy at kinetochores, a sentinel protein component of the spindle assembly 
checkpoint (SAC) [124]. In the absence of proper microtubule-kinetochore attachments, the SAC inhibits the activity of the anaphase promoting complex/cyclosome (APC/C) [133].

TRIM36 and TRIM17 control kinetochore proteins proteolysis in different manners. TRIM36 specifically associates with the microtubule structure as it co-localizes with $\alpha$-tubulin, one of the microtubule proteins, and has been identified as a novel specific centromere protein-H (CENP-H) binding protein [132]. TRIM36 not directly ubiquitinates and degrades CENP-H but may be involved in the proteolysis of CENP-H-associated proteins [132]. CENP-H is a centromere protein that has a central role in directing the assembly of the outer kinetochore and regulates the dynamics of microtubules that are embedded in kinetochores [134]. CENP-H aberrant expression causes chromosome mis-aggregation and plays an important role in the chromosomal instability frequently observed in cancers $[135,136]$. TRIM36 overexpression decelerates the cell cycle and attenuates cell growth, preventing the recruitment of CENP-H to centromeres. This evidence relates TRIM36-mediated control of kinetochore proteins with its effects on chromosomal instability and carcinogenesis [132].

TRIM17/(terf) interacts with the kinetochore protein ZWINT and degrades ZWINT protein in a proteasome dependent manner, through its ubiquitination [17]. Interestingly, it is known that ZWINT knockdown causes a chromosome bridge phenotype, abrogates the mitotic arrest and triggers cell death [137]. ZWINT also interacts with ZW10, a protein that is required for chromosome motility and spindle checkpoint control [138].

\subsection{TRIMs at the End of Mitosis: A Possible Role at Midbody Level}

TRIM proteins can also contribute to midbodies abundance, possibly through the autophagic removal of midbodies, immediately after cytokinesis. Midbodies are dense protein structures, containing the remnants of the cell division machinery [139]. They are formed at the site of abscission, are inherited by one of the two daughter cells and are removed by autophagy [139]. Several TRIMs like TRIM17, TRIM21, TRIM47, and TRIM76 control the number of midbodies per cell [140].

As an example TRIM17 co-localizes with or forms rings around midbodies [140]. TRIM17 knockdown causes an increase of midbodies number and size, indicative of less midbodies degradation that contributes to the autophagy-dependent removal of midbodies [140].

\section{Conclusions}

As discussed in this review, TRIM proteins regulate cell cycle progression and mitosis at different stages. Deregulation of TRIMs expression during cell cycle is directly related to an increase in the percentage of cells into a specific cell cycle phase (G1-S-G2 or M), modulating cell proliferation signals and resistance to cell death. Moreover, some TRIM proteins expression and localization is dependent on the progression and alternation of the different cell cycle phases. The cell cycle phase in which TRIM proteins are most involved is the mitosis. During mitosis TRIMs superfamily has been shown to exert important roles in the regulation of the main components of the mitotic spindle machinery, including kinetochores, centrosomes and midbodies that are important elements for ensuring chromosomes orientation and segregation to be performed correctly.

All the evidences collected and discussed in this review show that TRIM proteins may act as oncogenes or tumor suppressor genes, controlling cell proliferation and mitosis.

Author Contributions: S.V. and G.M. conceived the review and wrote the manuscript.

Funding: This work has been in part supported by Italian Ministry of Health to G.M. The funder had no role in study design, data collection and analysis, decision to publish or preparation of the manuscript.

Conflicts of Interest: The authors declare no conflict of interest. 


\section{References}

1. Bai, J.; Li, Y.; Zhang, G. Cell cycle regulation and anticancer drug discovery. Cancer Biol. Med. 2017, 14, 348-362. [CrossRef] [PubMed]

2. Singh, B.; Wu, P.J. Regulation of the program of DNA replication by CDK: New findings and perspectives. Curr. Genet. 2019, 65, 79-85. [CrossRef] [PubMed]

3. Mitelman, F. Chromosomes, genes, and cancer. CA Cancer J. Clin. 1994, 44, 133-135. [CrossRef]

4. Manic, G.; Corradi, F.; Sistigu, A.; Siteni, S.; Vitale, I. Molecular Regulation of the Spindle Assembly Checkpoint by Kinases and Phosphatases. Int. Rev. Cell. Mol. Biol. 2017, 328, 105-161. [CrossRef]

5. Fournane, S.; Krupina, K.; Kleiss, C.; Sumara, I. Decoding ubiquitin for mitosis. Genes Cancer 2012, 3, 697-711. [CrossRef]

6. Glotzer, M. The molecular requirements for cytokinesis. Science 2005, 307, 1735-1739. [CrossRef] [PubMed]

7. Guertin, D.A.; Trautmann, S.; McCollum, D. Cytokinesis in eukaryotes. Microbiol. Mol. Biol. Rev. 2002, 66, 155-178. [CrossRef]

8. McCollum, D. Cytokinesis: The central spindle takes center stage. Curr. Biol. 2004, 14, R953-R955. [CrossRef] [PubMed]

9. Reymond, A.; Meroni, G.; Fantozzi, A.; Merla, G.; Cairo, S.; Luzi, L.; Riganelli, D.; Zanaria, E.; Messali, S.; Cainarca, S.; et al. The tripartite motif family identifies cell compartments. EMBO J. 2001, 20, 2140-2151. [CrossRef]

10. Hatakeyama, S. TRIM Family Proteins: Roles in Autophagy, Immunity, and Carcinogenesis. Trends Biochem. Sci. 2017, 42, 297-311. [CrossRef] [PubMed]

11. Nisole, S.; Stoye, J.P.; Saib, A. TRIM family proteins: Retroviral restriction and antiviral defence. Nat. Rev. Microbiol. 2005, 3, 799-808. [CrossRef]

12. Meroni, G.; Diez-Roux, G. TRIM/RBCC, a novel class of 'single protein RING finger' E3 ubiquitin ligases. Bioessays 2005, 27, 1147-1157. [CrossRef]

13. Uchil, P.D.; Quinlan, B.D.; Chan, W.T.; Luna, J.M.; Mothes, W. TRIM E3 ligases interfere with early and late stages of the retroviral life cycle. PLoS Pathog. 2008, 4, e16. [CrossRef]

14. Crawford, L.J.; Johnston, C.K.; Irvine, A.E. TRIM proteins in blood cancers. J. Cell Commun. Signal 2018, 12, 21-29. [CrossRef]

15. Borlepawar, A.; Frey, N.; Rangrez, A.Y. A systematic view on E3 ligase Ring TRIMmers with a focus on cardiac function and disease. Trends Cardiovasc. Med. 2019, 29, 1-8. [CrossRef]

16. Gushchina, L.V.; Kwiatkowski, T.A.; Bhattacharya, S.; Weisleder, N.L. Conserved structural and functional aspects of the tripartite motif gene family point towards therapeutic applications in multiple diseases. Pharmacol. Ther. 2018, 185, 12-25. [CrossRef]

17. Endo, H.; Ikeda, K.; Urano, T.; Horie-Inoue, K.; Inoue, S. Terf/TRIM17 stimulates degradation of kinetochore protein ZWINT and regulates cell proliferation. J. Biochem. 2012, 151, 139-144. [CrossRef]

18. Hicke, L.; Dunn, R. Regulation of membrane protein transport by ubiquitin and ubiquitin-binding proteins. Annu. Rev. Cell Dev. Biol. 2003, 19, 141-172. [CrossRef]

19. Di Fiore, P.P.; Polo, S.; Hofmann, K. When ubiquitin meets ubiquitin receptors: A signalling connection. Nat. Rev. Mol. Cell Biol. 2003, 4, 491-497. [CrossRef]

20. Ikeda, F.; Crosetto, N.; Dikic, I. What determines the specificity and outcomes of ubiquitin signaling? Cell 2010, 143, 677-681. [CrossRef]

21. Ikeda, F.; Dikic, I. Atypical ubiquitin chains: New molecular signals. 'Protein Modifications: Beyond the Usual Suspects' review series. EMBO Rep. 2008, 9, 536-542. [CrossRef]

22. Polge, C.; Uttenweiler-Joseph, S.; Leulmi, R.; Heng, A.E.; Burlet-Schiltz, O.; Attaix, D.; Taillandier, D. Deciphering the ubiquitin proteome: Limits and advantages of high throughput global affinity purification-mass spectrometry approaches. Int. J. Biochem. Cell Biol. 2013, 45, 2136-2146. [CrossRef]

23. Grice, G.L.; Nathan, J.A. The recognition of ubiquitinated proteins by the proteasome. Cell Mol. Life Sci. 2016, 73, 3497-3506. [CrossRef]

24. Qi, Z.X.; Cai, J.J.; Chen, L.C.; Yue, Q.; Gong, Y.; Yao, Y.; Mao, Y. TRIM28 as an independent prognostic marker plays critical roles in glioma progression. J. Neurooncol. 2016, 126, 19-26. [CrossRef]

25. Xu, W.; Xu, B.; Yao, Y.; Yu, X.; Cao, H.; Zhang, J.; Liu, J.; Sheng, H. RNA interference against TRIM29 inhibits migration and invasion of colorectal cancer cells. Oncol. Rep. 2016, 36, 1411-1418. [CrossRef] 
26. Benke, S.; Agerer, B.; Haas, L.; Stoger, M.; Lercher, A.; Gabler, L.; Kiss, I.; Scinicariello, S.; Berger, W.; Bergthaler, A.; et al. Human tripartite motif protein 52 is required for cell context-dependent proliferation. Oncotarget 2018, 9, 13565-13581. [CrossRef]

27. Zhang, Y.; Tao, R.; Wu, S.S.; Xu, C.C.; Wang, J.L.; Chen, J.; Yu, Y.S.; Tang, Z.H.; Chen, X.H.; Zang, G.Q. TRIM52 up-regulation in hepatocellular carcinoma cells promotes proliferation, migration and invasion through the ubiquitination of PPM1A. J. Exp. Clin. Cancer Res. 2018, 37, 116. [CrossRef]

28. Aierken, G.; Seyiti, A.; Alifu, M.; Kuerban, G. Knockdown of Tripartite-59 (TRIM59) Inhibits Cellular Proliferation and Migration in Human Cervical Cancer Cells. Oncol. Res. 2017, 25, 381-388. [CrossRef]

29. Zhan, W.; Han, T.; Zhang, C.; Xie, C.; Gan, M.; Deng, K.; Fu, M.; Wang, J.B. TRIM59 Promotes the Proliferation and Migration of Non-Small Cell Lung Cancer Cells by Upregulating Cell Cycle Related Proteins. PLoS ONE 2015, 10, e0142596. [CrossRef]

30. Chen, Y.; Guo, Y.; Yang, H.; Shi, G.; Xu, G.; Shi, J.; Yin, N.; Chen, D. TRIM66 overexpresssion contributes to osteosarcoma carcinogenesis and indicates poor survival outcome. Oncotarget 2015, 6, 23708-23719. [CrossRef]

31. Tan, Z.; Liu, X.; Yu, E.; Wang, H.; Tang, L.; Wang, H.; Fu, C. Lentivirus-mediated RNA interference of tripartite motif 68 inhibits the proliferation of colorectal cancer cell lines SW1116 and HCT116 in vitro. Oncol. Lett. 2017, 13, 2649-2655. [CrossRef]

32. Venuto, S.; Castellana, S.; Monti, M.; Appolloni, I.; Fusilli, C.; Fusco, C.; Pucci, P.; Malatesta, P.; Mazza, T.; Merla, G.; et al. TRIM8-driven transcriptomic profile of neural stem cells identified glioma-related nodal genes and pathways. Biochim. Biophys. Acta Gen. Subj. 2019, 1863, 491-501. [CrossRef]

33. Caratozzolo, M.F.; Micale, L.; Turturo, M.G.; Cornacchia, S.; Fusco, C.; Marzano, F.; Augello, B.; D’Erchia, A.M.; Guerrini, L.; Pesole, G.; et al. TRIM8 modulates p53 activity to dictate cell cycle arrest. Cell Cycle 2012, 11, 511-523. [CrossRef]

34. Liu, Y.; Zhang, B.; Shi, T.; Qin, H. miR-182 promotes tumor growth and increases chemoresistance of human anaplastic thyroid cancer by targeting tripartite motif 8. Oncol. Targets Ther. 2017, 10, 1115-1122. [CrossRef]

35. Mu, X.; Li, H.; Zhou, L.; Xu, W. TRIM52 regulates the proliferation and invasiveness of lung cancer cells via the Wnt/betacatenin pathway. Oncol. Rep. 2019, 41, 3325-3334. [CrossRef]

36. Recio, C.; Guerra, B.; Guerra-Rodriguez, M.; Aranda-Tavio, H.; Martin-Rodriguez, P.; de Mirecki-Garrido, M.; Brito-Casillas, Y.; Garcia-Castellano, J.M.; Estevez-Braun, A.; Fernandez-Perez, L. Signal transducer and activator of transcription (STAT)-5: An opportunity for drug development in oncohematology. Oncogene 2019. [CrossRef]

37. Browning, L.; Patel, M.R.; Horvath, E.B.; Tawara, K.; Jorcyk, C.L. IL-6 and ovarian cancer: Inflammatory cytokines in promotion of metastasis. Cancer Manag. Res. 2018, 10, 6685-6693. [CrossRef]

38. Zoranovic, T.; Grmai, L.; Bach, E.A. Regulation of proliferation, cell competition, and cellular growth by the Drosophila JAK-STAT pathway. JAKSTAT 2013, 2, e25408. [CrossRef]

39. Xiong, H.; Zhang, Z.G.; Tian, X.Q.; Sun, D.F.; Liang, Q.C.; Zhang, Y.J.; Lu, R.; Chen, Y.X.; Fang, J.Y. Inhibition of JAK1, 2/STAT3 signaling induces apoptosis, cell cycle arrest, and reduces tumor cell invasion in colorectal cancer cells. Neoplasia 2008, 10, 287-297. [CrossRef]

40. Karimian, A.; Ahmadi, Y.; Yousefi, B. Multiple functions of p21 in cell cycle, apoptosis and transcriptional regulation after DNA damage. DNA Repair 2016, 42, 63-71. [CrossRef]

41. Xu, G.; Guo, Y.; Xu, D.; Wang, Y.; Shen, Y.; Wang, F.; Lv, Y.; Song, F.; Jiang, D.; Zhang, Y.; et al. TRIM14 regulates cell proliferation and invasion in osteosarcoma via promotion of the AKT signaling pathway. Sci. Rep. 2017, 7, 42411. [CrossRef]

42. Caratozzolo, M.F.; Valletti, A.; Gigante, M.; Aiello, I.; Mastropasqua, F.; Marzano, F.; Ditonno, P.; Carrieri, G.; Simonnet, H.; D'Erchia, A.M.; et al. TRIM8 anti-proliferative action against chemo-resistant renal cell carcinoma. Oncotarget 2014, 5, 7446-7457. [CrossRef] [PubMed]

43. Micale, L.; Fusco, C.; Fontana, A.; Barbano, R.; Augello, B.; De Nittis, P.; Copetti, M.; Pellico, M.T.; Mandriani, B.; Cocciadiferro, D.; et al. TRIM8 downregulation in glioma affects cell proliferation and it is associated with patients survival. BMC Cancer 2015, 15, 470. [CrossRef]

44. Czerwinska, P.; Mazurek, S.; Wiznerowicz, M. The complexity of TRIM28 contribution to cancer. J. Biomed. Sci. 2017, 24, 63. [CrossRef] 
45. Wei, C.; Cheng, J.; Zhou, B.; Zhu, L.; Khan, M.A.; He, T.; Zhou, S.; He, J.; Lu, X.; Chen, H.; et al. Tripartite motif containing 28 (TRIM28) promotes breast cancer metastasis by stabilizing TWIST1 protein. Sci. Rep. 2016, 6, 29822. [CrossRef]

46. Wang, Y.; Jiang, J.; Li, Q.; Ma, H.; Xu, Z.; Gao, Y. KAP1 is overexpressed in hepatocellular carcinoma and its clinical significance. Int. J. Clin. Oncol. 2016, 21, 927-933. [CrossRef] [PubMed]

47. Pan, S.; Deng, Y.; Fu, J.; Zhang, Y.; Zhang, Z.; Ru, X.; Qin, X. TRIM52 promotes colorectal cancer cell proliferation through the STAT3 signaling. Cancer Cell Int. 2019, 19, 57. [CrossRef]

48. Yang, W.; Liu, L.; Li, C.; Luo, N.; Chen, R.; Li, L.; Yu, F.; Cheng, Z. TRIM52 plays an oncogenic role in ovarian cancer associated with NF-kB pathway. Cell Death Dis. 2018, 9, 908. [CrossRef] [PubMed]

49. Yanagi, T.; Watanabe, M.; Hata, H.; Kitamura, S.; Imafuku, K.; Yanagi, H.; Homma, A.; Wang, L.; Takahashi, H.; Shimizu, H.; et al. Loss of TRIM29 Alters Keratin Distribution to Promote Cell Invasion in Squamous Cell Carcinoma. Cancer Res. 2018, 78, 6795-6806. [CrossRef]

50. Song, X.; Fu, C.; Yang, X.; Sun, D.; Zhang, X.; Zhang, J. Tripartite motif-containing 29 as a novel biomarker in non-small cell lung cancer. Oncol. Lett. 2015, 10, 2283-2288. [CrossRef]

51. Liu, C.; Huang, X.; Hou, S.; Hu, B.; Li, H. Silencing of tripartite motif (TRIM) 29 inhibits proliferation and invasion and increases chemosensitivity to cisplatin in human lung squamous cancer NCI-H520 cells. Thorac. Cancer 2015, 6, 31-37. [CrossRef]

52. Qiu, F.; Xiong, J.P.; Deng, J.; Xiang, X.J. TRIM29 functions as an oncogene in gastric cancer and is regulated by miR-185. Int. J. Clin. Exp. Pathol. 2015, 8, 5053-5061.

53. Spike, C.A.; Coetzee, D.; Eichten, C.; Wang, X.; Hansen, D.; Greenstein, D. The TRIM-NHL protein LIN-41 and the OMA RNA-binding proteins antagonistically control the prophase-to-metaphase transition and growth of Caenorhabditis elegans oocytes. Genetics 2014, 198, 1535-1558. [CrossRef]

54. Zhang, Y.; Feng, Y.; Ji, D.; Wang, Q.; Qian, W.; Wang, S.; Zhang, Z.; Ji, B.; Zhang, C.; Sun, Y.; et al. TRIM27 functions as an oncogene by activating epithelial-mesenchymal transition and $\mathrm{p}-\mathrm{AKT}$ in colorectal cancer. Int. J. Oncol. 2018, 53, 620-632. [CrossRef]

55. Lu, H.; Graham, R.P.; Seethala, R.; Chute, D. Intraductal Carcinoma of Salivary Glands Harboring TRIM27-RET Fusion with Mixed Low Grade and Apocrine Types. Head Neck Pathol. 2019. [CrossRef]

56. Ma, Y.; Wei, Z.; Bast, R.C., Jr.; Wang, Z.; Li, Y.; Gao, M.; Liu, Y.; Wang, X.; Guo, C.; Zhang, L.; et al. Downregulation of TRIM27 expression inhibits the proliferation of ovarian cancer cells in vitro and in vivo. Lab. Investig. 2016, 96, 37-48. [CrossRef]

57. Jiang, J.; Xie, C.; Liu, Y.; Shi, Q.; Chen, Y. Up-regulation of miR-383-5p suppresses proliferation and enhances chemosensitivity in ovarian cancer cells by targeting TRIM27. Biomed. Pharmacother. 2019, 109, 595-601. [CrossRef]

58. Feng, S.; Cai, X.; Li, Y.; Jian, X.; Zhang, L.; Li, B. Tripartite motif-containing 14 (TRIM14) promotes epithelial-mesenchymal transition via ZEB2 in glioblastoma cells. J. Exp. Clin. Cancer Res. 2019, 38, 57. [CrossRef]

59. Jin, Z.; Li, H.; Hong, X.; Ying, G.; Lu, X.; Zhuang, L.; Wu, S. TRIM14 promotes colorectal cancer cell migration and invasion through the SPHK1/STAT3 pathway. Cancer Cell Int. 2018, 18, 202. [CrossRef]

60. Wang, F.; Ruan, L.; Yang, J.; Zhao, Q.; Wei, W. TRIM14 promotes the migration and invasion of gastric cancer by regulating epithelialtomesenchymal transition via activation of AKT signaling regulated by miR1955p. Oncol. Rep. 2018, 40, 3273-3284. [CrossRef]

61. Dai, H.Y.; Ma, Y.; Da, Z.; Hou, X.M. Knockdown of TRIM66 inhibits malignant behavior and epithelial-mesenchymal transition in non-small cell lung cancer. Pathol. Res. Pract. 2018, 214, 1130-1135. [CrossRef]

62. Ma, Y.; Dai, H.Y.; Zhang, F.; Zhao, D. TRIM66 expression in non-small cell lung cancer: A new predictor of prognosis. Cancer Biomark. 2017, 20, 309-315. [CrossRef]

63. Bell, J.L.; Malyukova, A.; Kavallaris, M.; Marshall, G.M.; Cheung, B.B. TRIM16 inhibits neuroblastoma cell proliferation through cell cycle regulation and dynamic nuclear localization. Cell Cycle 2013, 12, 889-898. [CrossRef]

64. Tan, H.; Qi, J.; Chu, G.; Liu, Z. Tripartite Motif 16 Inhibits the Migration and Invasion in Ovarian Cancer Cells. Oncol. Res. 2017, 25, 551-558. [CrossRef]

65. Li, L.; Dong, L.; Qu, X.; Jin, S.; Lv, X.; Tan, G. Tripartite motif 16 inhibits hepatocellular carcinoma cell migration and invasion. Int. J. Oncol. 2016, 48, 1639-1649. [CrossRef] 
66. Shen, H.; Zhang, J.; Zhang, Y.; Feng, Q.; Wang, H.; Li, G.; Jiang, W.; Li, X. Knockdown of tripartite motif 59 (TRIM59) inhibits proliferation in cholangiocarcinoma via the PI3K/AKT/mTOR signalling pathway. Gene 2019, 698, 50-60. [CrossRef]

67. Tan, P.; Ye, Y.; He, L.; Xie, J.; Jing, J.; Ma, G.; Pan, H.; Han, L.; Han, W.; Zhou, Y. TRIM59 promotes breast cancer motility by suppressing p62-selective autophagic degradation of PDCD10. PLoS Biol. 2018, 16, e3000051. [CrossRef]

68. Sun, Y.; Ji, B.; Feng, Y.; Zhang, Y.; Ji, D.; Zhu, C.; Wang, S.; Zhang, C.; Zhang, D.; Sun, Y. TRIM59 facilitates the proliferation of colorectal cancer and promotes metastasis via the PI3K/AKT pathway. Oncol. Rep. 2017, 38, 43-52. [CrossRef]

69. Hu, S.H.; Zhao, M.J.; Wang, W.X.; Xu, C.W.; Wang, G.D. TRIM59 is a key regulator of growth and migration inrenal cell carcinoma. Cell Mol. Biol. 2017, 63, 68-74. [CrossRef]

70. Pan, Y.; Zhang, R.; Chen, H.; Chen, W.; Wu, K.; Lv, J. Expression of Tripartite Motif-Containing Proteactiin 11 (TRIM11) is Associated with the Progression of Human Prostate Cancer and is Downregulated by MicroRNA-5193. Med. Sci. Monit. 2019, 25, 98-106. [CrossRef]

71. Chen, Y.; Sun, J.; Ma, J. Proliferation and invasion of ovarian cancer cells are suppressed by knockdown of TRIM11. Oncol. Lett. 2017, 14, 2125-2130. [CrossRef]

72. Wang, X.; Shi, W.; Shi, H.; Lu, S.; Wang, K.; Sun, C.; He, J.; Jin, W.; Lv, X.; Zou, H.; et al. TRIM11 overexpression promotes proliferation, migration and invasion of lung cancer cells. J. Exp. Clin. Cancer Res. 2016, 35, 100. [CrossRef]

73. Liu, J.; Rao, J.; Lou, X.; Zhai, J.; Ni, Z.; Wang, X. Upregulated TRIM11 Exerts its Oncogenic Effects in Hepatocellular Carcinoma Through Inhibition of P53. Cell Physiol. Biochem. 2017, 44, 255-266. [CrossRef]

74. Zhang, Z.; Xu, C.; Zhang, X.; Huang, L.; Zheng, C.; Chen, H.; Wang, Y.; Ju, H.; Yao, Q. TRIM11 Upregulation Contributes to Proliferation, Invasion, and EMT of Hepatocellular Carcinoma Cells. Oncol. Res. 2017, 25, 691-699. [CrossRef]

75. Yao, Y.; Liu, Z.; Guo, H.; Huang, S.; Zhong, M.; Deng, J.; Xiong, J. Elevated TRIM23 expression predicts poor prognosis in Chinese gastric cancer. Pathol. Res. Pract. 2018, 214, 2062-2068. [CrossRef]

76. Wang, F.Q.; Han, Y.; Yao, W.; Yu, J. Prognostic relevance of tripartite motif containing 24 expression in colorectal cancer. Pathol. Res. Pract. 2017, 213, 1271-1275. [CrossRef]

77. Sun, N.; Xue, Y.; Dai, T.; Li, X.; Zheng, N. Tripartite motif containing 25 promotes proliferation and invasion of colorectal cancer cells through TGF-beta signaling. Biosci. Rep. 2017, 37. [CrossRef]

78. Wang, S.; Kollipara, R.K.; Humphries, C.G.; Ma, S.H.; Hutchinson, R.; Li, R.; Siddiqui, J.; Tomlins, S.A.; Raj, G.V.; Kittler, R. The ubiquitin ligase TRIM25 targets ERG for degradation in prostate cancer. Oncotarget 2016, 7, 64921-64931. [CrossRef]

79. Zhu, Z.; Wang, Y.; Zhang, C.; Yu, S.; Zhu, Q.; Hou, K.; Yan, B. TRIM25 blockade by RNA interference inhibited migration and invasion of gastric cancer cells through TGF-beta signaling. Sci. Rep. 2016, 6, 19070. [CrossRef]

80. Guo, P.; Ma, X.; Zhao, W.; Huai, W.; Li, T.; Qiu, Y.; Zhang, Y.; Han, L. TRIM31 is upregulated in hepatocellular carcinoma and promotes disease progression by inducing ubiquitination of TSC1-TSC2 complex. Oncogene 2018, 37, 478-488. [CrossRef]

81. Tang, S.L.; Gao, Y.L.; Wen-Zhong, H. Knockdown of TRIM37 suppresses the proliferation, migration and invasion of glioma cells through the inactivation of PI3K/Akt signaling pathway. Biomed. Pharmacother. 2018, 99, 59-64. [CrossRef] [PubMed]

82. Liang, Q.; Tang, C.; Tang, M.; Zhang, Q.; Gao, Y.; Ge, Z. TRIM47 is up-regulated in colorectal cancer, promoting ubiquitination and degradation of SMAD4. J. Exp. Clin. Cancer Res. 2019, 38, 159. [CrossRef]

83. Fujimura, T.; Inoue, S.; Urano, T.; Takayama, K.; Yamada, Y.; Ikeda, K.; Obinata, D.; Ashikari, D.; Takahashi, S.; Homma, Y. Increased Expression of Tripartite Motif (TRIM) 47 Is a Negative Prognostic Predictor in Human Prostate Cancer. Clin. Genitourin. Cancer 2016, 14, 298-303. [CrossRef] [PubMed]

84. Wei, W.S.; Chen, X.; Guo, L.Y.; Li, X.D.; Deng, M.H.; Yuan, G.J.; He, L.Y.; Li, Y.H.; Zhang, Z.L.; Jiang, L.J.; et al. TRIM65 supports bladder urothelial carcinoma cell aggressiveness by promoting ANXA2 ubiquitination and degradation. Cancer Lett. 2018, 435, 10-22. [CrossRef] 
85. Ren, H.; Xu, Y.; Wang, Q.; Jiang, J.; Wudumuli; Hui, L.; Zhang, Q.; Zhang, X.; Wang, E.; Sun, L.; et al. E3 ubiquitin ligase tripartite motif-containing 71 promotes the proliferation of non-small cell lung cancer through the inhibitor of kappaB-alpha/nuclear factor kappaB pathway. Oncotarget 2018, 9, 10880-10890. [CrossRef]

86. Xiao, W.; Wang, X.; Wang, T.; Xing, J. TRIM2 downregulation in clear cell renal cell carcinoma affects cell proliferation, migration, and invasion and predicts poor patients' survival. Cancer Manag. Res. 2018, 10, 5951-5964. [CrossRef] [PubMed]

87. Song, Y.; Guo, Q.; Gao, S.; Hua, K. Tripartite motif-containing protein 3 plays a role of tumor inhibitor in cervical cancer. Biochem. Biophys. Res. Commun. 2018, 498, 686-692. [CrossRef]

88. Chao, J.; Zhang, X.F.; Pan, Q.Z.; Zhao, J.J.; Jiang, S.S.; Wang, Y.; Zhang, J.H.; Xia, J.C. Decreased expression of TRIM3 is associated with poor prognosis in patients with primary hepatocellular carcinoma. Med. Oncol. 2014, 31, 102. [CrossRef] [PubMed]

89. Chen, W.; Lu, C.; Hong, J. TRIM15 Exerts Anti-Tumor Effects Through Suppressing Cancer Cell Invasion in Gastric Adenocarcinoma. Med. Sci. Monit. 2018, 24, 8033-8041. [CrossRef]

90. Lee, O.H.; Lee, J.; Lee, K.H.; Woo, Y.M.; Kang, J.H.; Yoon, H.G.; Bae, S.K.; Songyang, Z.; Oh, S.H.; Choi, Y. Role of the focal adhesion protein TRIM15 in colon cancer development. Biochim. Biophys. Acta 2015, 1853, 409-421. [CrossRef]

91. Wang, Y.; He, D.; Yang, L.; Wen, B.; Dai, J.; Zhang, Q.; Kang, J.; He, W.; Ding, Q.; He, D. TRIM26 functions as a novel tumor suppressor of hepatocellular carcinoma and its downregulation contributes to worse prognosis. Biochem. Biophys. Res. Commun. 2015, 463, 458-465. [CrossRef]

92. Kimura, N.; Yamada, Y.; Takayama, K.I.; Fujimura, T.; Takahashi, S.; Kume, H.; Inoue, S. Androgen-responsive tripartite motif 36 enhances tumor-suppressive effect by regulating apoptosis-related pathway in prostate cancer. Cancer Sci. 2018, 109, 3840-3852. [CrossRef] [PubMed]

93. Zhang, J.; Zhang, C.; Cui, J.; Ou, J.; Han, J.; Qin, Y.; Zhi, F.; Wang, R.F. TRIM45 functions as a tumor suppressor in the brain via its E3 ligase activity by stabilizing p53 through K63-linked ubiquitination. Cell Death Dis. 2017, 8, e2831. [CrossRef]

94. Ma, X.; Ma, X.; Qiu, Y.; Zhu, L.; Lin, Y.; You, Y.; Ma, D.; Qin, Z.; Sun, C.; Zhao, Y.; et al. TRIM50 suppressed hepatocarcinoma progression through directly targeting SNAIL for ubiquitous degradation. Cell Death Dis. 2018, 9, 608. [CrossRef] [PubMed]

95. Liu, M.; Zhang, X.; Cai, J.; Li, Y.; Luo, Q.; Wu, H.; Yang, Z.; Wang, L.; Chen, D. Downregulation of TRIM58 expression is associated with a poor patient outcome and enhances colorectal cancer cell invasion. Oncol. Rep. 2018, 40, 1251-1260. [CrossRef] [PubMed]

96. Kajiura, K.; Masuda, K.; Naruto, T.; Kohmoto, T.; Watabnabe, M.; Tsuboi, M.; Takizawa, H.; Kondo, K.; Tangoku, A.; Imoto, I. Frequent silencing of the candidate tumor suppressor TRIM58 by promoter methylation in early-stage lung adenocarcinoma. Oncotarget 2017, 8, 2890-2905. [CrossRef]

97. Quintas-Cardama, A.; Zhang, N.; Qiu, Y.H.; Post, S.; Creighton, C.J.; Cortes, J.; Coombes, K.R.; Kornblau, S.M. Loss of TRIM62 expression is an independent adverse prognostic factor in acute myeloid leukemia. Clin. Lymphoma Myeloma Leuk. 2015, 15, 115-127. [CrossRef]

98. Lazzari, E.; Meroni, G. TRIM32 ubiquitin E3 ligase, one enzyme for several pathologies: From muscular dystrophy to tumours. Int. J. Biochem. Cell Biol. 2016, 79, 469-477. [CrossRef]

99. Yin, H.; Li, Z.; Chen, J.; Hu, X. Expression and the potential functions of TRIM32 in lung cancer tumorigenesis. J. Cell Biochem. 2019, 120, 5232-5243. [CrossRef] [PubMed]

100. Izumi, H.; Kaneko, Y. Trim32 facilitates degradation of MYCN on spindle poles and induces asymmetric cell division in human neuroblastoma cells. Cancer Res. 2014, 74, 5620-5630. [CrossRef]

101. Sun, S.; Li, W.; Ma, X.; Luan, H. Long Noncoding RNA LINC00265 Promotes Glycolysis and Lactate Production of Colorectal Cancer through Regulating of miR-216b-5p/TRIM44 Axis. Digestion 2019, 1-10. [CrossRef]

102. Xiong, D.; Jin, C.; Ye, X.; Qiu, B.; Jianjun, X.; Zhu, S.; Xiang, L.; Wu, H.; Yongbing, W. TRIM44 promotes human esophageal cancer progression via the AKT/mTOR pathway. Cancer Sci. 2018, 109, 3080-3092. [CrossRef]

103. Zhou, Z.; Liu, Y.; Ma, M.; Chang, L. Knockdown of TRIM44 inhibits the proliferation and invasion in papillary thyroid cancer cells through suppressing the Wnt/beta-catenin signaling pathway. Biomed. Pharmacother. 2017, 96, 98-103. [CrossRef] 
104. Kawabata, H.; Azuma, K.; Ikeda, K.; Sugitani, I.; Kinowaki, K.; Fujii, T.; Osaki, A.; Saeki, T.; Horie-Inoue, K.; Inoue, S. TRIM44 Is a Poor Prognostic Factor for Breast Cancer Patients as a Modulator of NF-kappaB Signaling. Int. J. Mol. Sci. 2017, 18, 1931. [CrossRef]

105. Tan, Y.; Yao, H.; Hu, J.; Liu, L. Knockdown of TRIM44 Inhibits the Proliferation and Invasion in Prostate Cancer Cells. Oncol. Res. 2017, 25, 1253-1259. [CrossRef] [PubMed]

106. Luo, Q.; Lin, H.; Ye, X.; Huang, J.; Lu, S.; Xu, L. Trim44 facilitates the migration and invasion of human lung cancer cells via the NF-kappaB signaling pathway. Int. J. Clin. Oncol. 2015, 20, 508-517. [CrossRef]

107. Yamada, Y.; Takayama, K.I.; Fujimura, T.; Ashikari, D.; Obinata, D.; Takahashi, S.; Ikeda, K.; Kakutani, S.; Urano, T.; Fukuhara, H.; et al. A novel prognostic factor TRIM44 promotes cell proliferation and migration, and inhibits apoptosis in testicular germ cell tumor. Cancer Sci. 2017, 108, 32-41. [CrossRef] [PubMed]

108. Wang, C.; Xu, J.; Fu, H.; Zhang, Y.; Zhang, X.; Yang, D.; Zhu, Z.; Wei, Z.; Hu, Z.; Yan, R.; et al. TRIM32 promotes cell proliferation and invasion by activating beta-catenin signalling in gastric cancer. J. Cell Mol. Med. 2018, 22, 5020-5028. [CrossRef]

109. Zhang, P.; Zhang, H.; Wang, Y.; Zhang, P.; Qi, Y. Tripartite Motif-Containing Protein 59 (TRIM59) Promotes Epithelial Ovarian Cancer Progression via the Focal Adhesion Kinase(FAK)/AKT/Matrix Metalloproteinase (MMP) Pathway. Med. Sci. Monit. 2019, 25, 3366-3373. [CrossRef]

110. Wang, Y.; Zhou, Z.; Wang, X.; Zhang, X.; Chen, Y.; Bai, J.; Di, W. TRIM59 Is a Novel Marker of Poor Prognosis and Promotes Malignant Progression of Ovarian Cancer by Inducing Annexin A2 Expression. Int. J. Biol. Sci. 2018, 14, 2073-2082. [CrossRef] [PubMed]

111. Chen, W.; Zhao, K.; Miao, C.; Xu, A.; Zhang, J.; Zhu, J.; Su, S.; Wang, Z. Silencing Trim59 inhibits invasion/migration and epithelial-to-mesenchymal transition via TGF-beta/Smad2/3 signaling pathway in bladder cancer cells. Onco. Targets Ther. 2017, 10, 1503-1512. [CrossRef] [PubMed]

112. Liang, J.; Xing, D.; Li, Z.; Shen, J.; Zhao, H.; Li, S. TRIM59 is upregulated and promotes cell proliferation and migration in human osteosarcoma. Mol. Med. Rep. 2016, 13, 5200-5206. [CrossRef]

113. Lin, W.Y.; Wang, H.; Song, X.; Zhang, S.X.; Zhou, P.S.; Sun, J.M.; Li, J.S. Knockdown of tripartite motif 59 (TRIM59) inhibits tumor growth in prostate cancer. Eur. Rev. Med. Pharmacol. Sci. 2016, 20, 4864-4873.

114. Monda, J.K.; Cheeseman, I.M. The kinetochore-microtubule interface at a glance. J. Cell Sci. $2018,131$. [CrossRef]

115. Musacchio, A.; Desai, A. A Molecular View of Kinetochore Assembly and Function. Biology 2017, 6, 5. [CrossRef]

116. Ansari, D.; Del Pino Bellido, C.; Bauden, M.; Andersson, R. Centrosomal Abnormalities in Pancreatic Cancer: Molecular Mechanisms and Clinical Implications. Anticancer Res. 2018, 38, 1241-1245. [CrossRef]

117. Nigg, E.A.; Stearns, T. The centrosome cycle: Centriole biogenesis, duplication and inherent asymmetries. Nat. Cell Biol. 2011, 13, 1154-1160. [CrossRef]

118. Moura, M.; Conde, C. Phosphatases in Mitosis: Roles and Regulation. Biomolecules 2019, 9, 55. [CrossRef]

119. Short, K.M.; Cox, T.C. Subclassification of the RBCC/TRIM superfamily reveals a novel motif necessary for microtubule binding. J. Biol. Chem. 2006, 281, 8970-8980. [CrossRef]

120. Ozato, K.; Shin, D.M.; Chang, T.H.; Morse III, H.C. TRIM family proteins and their emerging roles in innate immunity. Nat. Rev. Immunol. 2008, 8, 849-860. [CrossRef]

121. D'Cruz, A.A.; Babon, J.J.; Norton, R.S.; Nicola, N.A.; Nicholson, S.E. Structure and function of the SPRY/B30.2 domain proteins involved in innate immunity. Protein Sci. 2013, 22, 1-10. [CrossRef] [PubMed]

122. Xu, Z.X.; Zou, W.X.; Lin, P.; Chang, K.S. A role for PML3 in centrosome duplication and genome stability. Mol. Cell. 2005, 17, 721-732. [CrossRef]

123. Petersson, J.; Lonnbro, P.; Herr, A.M.; Morgelin, M.; Gullberg, U.; Drott, K. The human IFN-inducible p53 target gene TRIM22 colocalizes with the centrosome independently of cell cycle phase. Exp. Cell Res. 2010, 316, 568-579. [CrossRef]

124. Sinnott, R.; Winters, L.; Larson, B.; Mytsa, D.; Taus, P.; Cappell, K.M.; Whitehurst, A.W. Mechanisms promoting escape from mitotic stress-induced tumor cell death. Cancer Res. 2014, 74, 3857-3869. [CrossRef]

125. Neo, S.H.; Itahana, Y.; Alagu, J.; Kitagawa, M.; Guo, A.K.; Lee, S.H.; Tang, K.; Itahana, K. TRIM28 Is an E3 Ligase for ARF-Mediated NPM1/B23 SUMOylation That Represses Centrosome Amplification. Mol. Cell. Biol. 2015, 35, 2851-2863. [CrossRef]

126. Lambrus, B.G.; Holland, A.J. A New Mode of Mitotic Surveillance. Trends Cell Biol. 2017, 27, $314-321$. [CrossRef] 
127. Liu, X.; Liu, Z.; Jang, S.W.; Ma, Z.; Shinmura, K.; Kang, S.; Dong, S.; Chen, J.; Fukasawa, K.; Ye, K. Sumoylation of nucleophosmin/B23 regulates its subcellular localization, mediating cell proliferation and survival. Proc. Natl. Acad. Sci. USA 2007, 104, 9679-9684. [CrossRef]

128. Lukasiewicz, K.B.; Lingle, W.L. Aurora A, centrosome structure, and the centrosome cycle. Environ. Mol. Mutagen 2009, 50, 602-619. [CrossRef] [PubMed]

129. Puram, S.V.; Kim, A.H.; Park, H.Y.; Anckar, J.; Bonni, A. The ubiquitin receptor S5a/Rpn10 links centrosomal proteasomes with dendrite development in the mammalian brain. Cell. Rep. 2013, 4, 19-30. [CrossRef]

130. Knoblich, J.A. Asymmetric cell division: Recent developments and their implications for tumour biology. Nat. Rev. Mol. Cell Biol. 2010, 11, 849-860. [CrossRef] [PubMed]

131. Nagpal, H.; Fukagawa, T. Kinetochore assembly and function through the cell cycle. Chromosoma 2016, 125, 645-659. [CrossRef] [PubMed]

132. Miyajima, N.; Maruyama, S.; Nonomura, K.; Hatakeyama, S. TRIM36 interacts with the kinetochore protein CENP-H and delays cell cycle progression. Biochem. Biophys. Res. Commun. 2009, 381, 383-387. [CrossRef] [PubMed]

133. Lischetti, T.; Nilsson, J. Regulation of mitotic progression by the spindle assembly checkpoint. Mol. Cell. Oncol. 2015, 2, e970484. [CrossRef]

134. Hu, L.; Huang, H.; Hei, M.; Yang, Y.; Li, S.; Liu, Y.; Dou, Z.; Wu, M.; Li, J.; Wang, G.Z.; et al. Structural analysis of fungal CENP-H/I/K homologs reveals a conserved assembly mechanism underlying proper chromosome alignment. Nucleic Acids Res. 2019, 47, 468-479. [CrossRef]

135. Matson, D.R.; Demirel, P.B.; Stukenberg, P.T.; Burke, D.J. A conserved role for COMA/CENP-H/I/N kinetochore proteins in the spindle checkpoint. Genes Dev. 2012, 26, 542-547. [CrossRef]

136. Tomonaga, T.; Matsushita, K.; Ishibashi, M.; Nezu, M.; Shimada, H.; Ochiai, T.; Yoda, K.; Nomura, F. Centromere protein $\mathrm{H}$ is up-regulated in primary human colorectal cancer and its overexpression induces aneuploidy. Cancer Res. 2005, 65, 4683-4689. [CrossRef]

137. Lin, Y.T.; Chen, Y.; Wu, G.; Lee, W.H. Hec1 sequentially recruits Zwint-1 and ZW10 to kinetochores for faithful chromosome segregation and spindle checkpoint control. Oncogene 2006, 25, 6901-6914. [CrossRef]

138. Wang, H.; Hu, X.; Ding, X.; Dou, Z.; Yang, Z.; Shaw, A.W.; Teng, M.; Cleveland, D.W.; Goldberg, M.L.; Niu, L.; et al. Human Zwint-1 specifies localization of Zeste White 10 to kinetochores and is essential for mitotic checkpoint signaling. J. Biol. Chem. 2004, 279, 54590-54598. [CrossRef] [PubMed]

139. Pohl, C.; Jentsch, S. Midbody ring disposal by autophagy is a post-abscission event of cytokinesis. Nat. Cell. Biol. 2009, 11, 65-70. [CrossRef] [PubMed]

140. Mandell, M.A.; Jain, A.; Kumar, S.; Castleman, M.J.; Anwar, T.; Eskelinen, E.L.; Johansen, T.; Prekeris, R.; Deretic, V. Correction: TRIM17 contributes to autophagy of midbodies while actively sparing other targets from degradation. J. Cell. Sci. 2017, 130, 1194. [CrossRef] 